\title{
Geological sketch and the non-karstic caves of the Bakony Mountains in Hungary
}

ESZTERHÁS, I. ${ }^{1}$ and SZENTES, G. ${ }^{2}$

(1) Köztársaság út 157, H-8045 Isztimér, Hungary, eszterhas.istvan@gmail.com

(2) Alte Frankfurter Str. 22 b, D-61118 Bad Vilbel, Germany, georgeszentes@yahoo.de

https://doi.org/10.17979/cadlaxe.2013.37.0.3579

\begin{abstract}
The about $4000 \mathrm{~km} 2$ Bakony Mountains form the most extensive region of the Trans-Danubien Mountains between Lake Balaton and Marcal River. They have a typical medium relief, including plateaux of various heights, and denudated fault blocks interspersed with inter mountain basins. In the southern and western areas of the mountains, basalt cones and basaltic sheets are frequently found. In the central area, the variously sloping landscape is inclined towards the blocks. Limestone and dolomite predominate, and there are extensive karst regions and numerous karst caves. Of course, from the point of view of the non-karstic caves, these regions are insignificant. Significantly smaller is the occurrence of quartziferous (sandstone and conglomerate) and basalt rocks, however 147 non-karstic cave are known in these rocks and, in addition, 35 artificial cavities, considered as caves, are listed. The authors describe the geology, the geomorphology and the non-karstic cave development of the Bakony Mountains. Furthermore, typical examples of the caves have been selected and presented according to the different rock formations and development types.
\end{abstract}

Key words: sandstone; geyserites; gas bubble; explosion cave; geyserite cave; tectonic cave; atectonic cave; break down cavity; consequence cave; talus cave; cavity between basalt columns; alkaline solution cave; ice cave; flooded cave. 


\section{INTRODUCTION}

The Bakony Mountains form a section of the $4000 \mathrm{~km} 2$ of the Trans-Danubien Mountains between Lake Balaton and Marcal River. They have a typical medium relief, including plateaux of various heights, and denudated fault blocks interspersed with intermontane basins. In the southern and western areas of the mountains, basalt cones and basaltic sheets are frequently found. In the central area, the variously sloping landscape is inclined towards the blocks. Limestone and dolomite predominate, and there are extensive karst regions and numerous karst caves. Of course, from the point of view of the non-karstic caves, these regions are insignificant.
As a result of systematic research by the Volcanspeleological Collective, 147 natural non-karst caves and 35 artificial cavities have been listed in the Bakony Mountains. Fifty-six non-karstic caves have developed in basalt. Forty-one caves are listed in the geyserite of the Tihanyi Peninsula. Thirtytwo non-karstic caves appear in the Miocene calcareous conglomerate and 10 caves are known in the Pannonian quartziferous sandstone. Furthermore, 7 caves have developed in basaltic tuff and one in loess. Artificial cavities have generally been dug in basalt tuff and loess (Fig. 1).

The present study intends to summarize the development of the non-karstic caves and to demonstrate their speleological significance. 


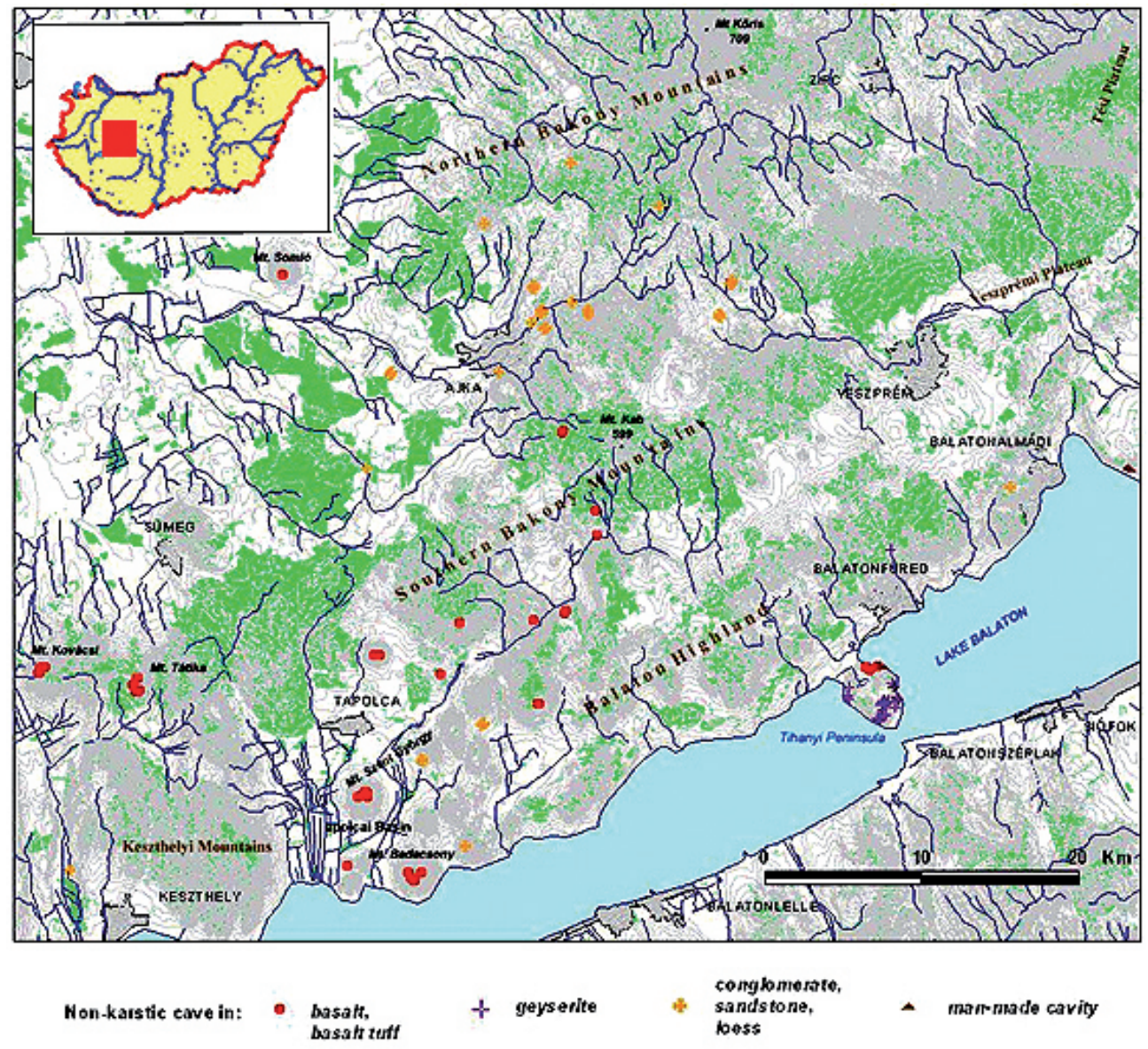

Fig. 1. Location of the non-karstic caves or the clusters of non-karstic caves in the Bakony Mountains

\section{SKETCH OF THE GEOMORPHOLOGY}

The Bakony Mountains make up the most extensive region of the TransDanubien Mountains (3974 km2) which extends from the Zala River Valley to the Móri Trench and from Lake Balaton to the Little Hungarian Plain. The mountains are divided into three main areas along NE-SW trending fault lines, the Northern Bakony Mountains, the Southern Bakony
Mountains and the Balaton Upland. Other less significant areas of the mountains are the Keszthelyi Mountains, the Tapolca Basin and the Bakony Foreland (Fig. 1). The Northern and Southern Bakony Mountains are divided by the Veszprém- Devecser Trench, while the Veszrém - Ngyvázsony Trench separates the Southern Bakony Mountains and the Balaton Upland. The Tertiary and Quaternary uplifts formed the present elevation of the region. Young 
tectonic movements uplifted the land more and more towards the north. The highest point of the mountains is Mount Köris $701 \mathrm{~m}$ above the sea level, which rises in the north of the region. The main constituents of this region are the karstic limestones and dolomites. Many characteristic surface and subsurface karstic forms are to be found in the covered and in the opened karst regions (JUHÁSZ, 1987).

The Northern Bakony Mountains make up the the highest and most extensive area in the region. The land itself is a forest covered karst, which is dotted with many romantic valleys. The creeks eroded the covering gravel sheet and have cut deep canyons into the underlying limestone or dolomite. The largest basin is the loess covered Zirci Basin, which is surrounded with the large blocks of the Northern Bakony Mountains. Surface water occurrence is insignificant, therefore, settlements are to be found only near the karst springs. The easternmost parts of the mountains are the Tési Plateau and the Bodajki Block. This is a karst region with creeks and dry valleys, with barren rock surface and patches of forest with sinkholes and caves.

Southern Bakony is surrounded by the towns of Veszprém - Devecser - Sümeg and Tapolca. The eastern part, the Veszprémi Plateau, is a barren dolomite plateau from 250 to $300 \mathrm{~m}$ above sea level. In the western part limestone is dominant and contains many diverse karstic features. South of the Séd Valley a layer of gravel covers a basalt plateau. The $601 \mathrm{~m}$ high Mount Kab and Mount Agár are the most extensive stratovolcanoes in the region. The basalt is underlain by limestone and pseudokarstic depressions which appear on the basalt surface due to karstic corrosion of the buried limestone layers. Fertile basins are also to be found in the western area. An unusual surface formation, an altiplanation surface, is the "Stone Sea" in the Kali Basin, whilst Castle Hill at Sümeg, a western block of the Southern Bakony, is composed of Cretaceous limeston.

The Keszthelyi Mountains, the westernmost part of the Bakony Mountains, are adjacent to the Balaton Uplands. The mountains consist of limestone and dolomite blocks, which are bordered on either side by steep multiple faults. Between the blocks several small basins are to be found. In the north-western part of the basalt formation the Mount Tátika Group occurs.

The volcanic series of the Balaton Upland is an intra-plate monogenetic volcanic formation. The volcanic landforms are composed of denudated maars, tuff rings, spatter cones, lava lakes, valleyfilling lava flows and lava fields. The basalt has broken through and covered the loose Pannonian sediments of the Tapolca Basin. The overlying hard basalt trap has prevented denudation and thus has developed witness buttes. In some witness buttes, for instant on Mount Szent György, spectacular columnar basalt forms occur. Volcanic activity has played an important role in the formation of the Tihanyi Peninsula. The Inner Lake and the Outer Lake are the apparent remains of two calderas (BUCKÓ, 1970). Several hundred geyser cones have developed as a result of postvolcanic activity (CHOLNOKY, 1931). The base formation of the peninsula is the yellowish white Pannonian sand and clay, which crops out in the steep banks of the Lake Balaton. In the postvolcanic period erosion has significantly denuded the volcanic forms themselves and revealed the fossil surface beneath the 
Pannonian sediments. Recent valley patterns and alluvial fans have developed over the complete Bakony Mountain range.

\section{GEOLOGICAL SETTINGS}

The Bakony Mountains are basically composed of sedimentary rocks, which have been superimposed by young basaltic formation and geyserite in the Tihanyi Peninsula (GYALOG, 2005).

The oldest formation is the Ordovician and Silurian series of phyllite and clay schist near the village of Alsóörs in the Balaton Upland.

Permian red sandstone and conglomerate overlie the folded Palaeozoic bedrock with angular unconformity. Large Permian outcrops are to be found in the eastern part of the Bakony Mountains and in the Balaton Upland. The thickness of the formation is some 800 m (JUHÁSZ, 1987).

The Triassic sequences have typical classical stratigraphy. The Lower Triassic strata are composed of clay shale and marl layers interspersed with thin laminated limestone and dolomite. This formation can be observed in the Southern Bakony Mountains and in the Balaton Upland. In the Middle Triassic, thick bedded dolomite has been deposited, associated to a lesser extent with limestone. This dolomite forms the Veszprémi Dolomite Plateau. Near the town of Balatonfüred, light coloured drab, bedded, nodular Füredi Limestone is characteristic, which reflects a basin facies development. The Upper Triassic thick bedded limestone and dolomite are to be found throughout the Bakony Mountains. The most prevalent and thickest rock is a carbonate platform formation, the thick bedded, light grey Great Dolomite or
Hauptdolomite. In the Northern Bakony Mountains, the Dachstein Limestone appears in a narrow belt.

The Lower- the Middle- and the Upper Jurassic formations are to be found throughout over in the Bakony Mountains. Limestone and marl series are typical of the Lower Jurassic among others on the Tési Plateau. Also associated with the Lower Jurassic period it is the black shale-related manganese ore deposit near the village of Úrkut. The red ammonitic limestone is a typical Middle Jurassic formation in the central region of the mountains. Limestone series also occur in the Upper Jurassic.

Cherty limestone was deposited in the Lower Cretaceous period in the Zirci Basin. Limestone was deposited in the Middle Cretaceous period. In the Upper Cretaceous marl, claey marl and coal seams formed near the settlements of Ajka and Csehbánya. A unique formation, which is economically important, is the Lower Cretaceous bauxite, which occurs extensively in the central region of the mountains.

In the Eocene, terrestrial red clay is overlain by coal measures in the Northern Bakony Mountains, which are, in turn, overlain either by Eocene Nummulites Limestone or by algal carbonate platform sediments. The Nummulites Limestone often overlays the bauxite deposits (GYALOG, 2005). Allothigene bauxite accompanied by marl and claey marl has deposited in the Oligocene.

The Miocene sedimentary sequence is either basin fill in the intermontane basins or occurs in the rims of the basins. Coarse sand and conglomerate together with calcareous sandstone form the Lower Miocene in the Eastern Bakony Mountains, which is overlain by claey, sandy coal seams in the Várpalotai and 
Szentgáli Basins. Extensive Lajtha Limestone deposits represent the Middle Miocene in both the Western Bakony Mountains and in the Tapolcai Basin. Coarse-grained calcareous sandstone and conglomerate are to be found in the central and southern part of the mountains, and are significant as regards nonkarstic cave development.

The topset beds of the basins are limnic sandy and claey sediments, which were deposited in the Upper Pannonian Stage of the Pliocene. In some places, quartziferous sandstone occurs, which is suitable for nonkarstic cave development.

In the Upper Pannonian, intensive basalt volcanism has occurred, which has resulted in alkaline basalt and basalt tuff. Occasionally the basalt structure is scoriaceous. The witness buttes and tuff rings in the Tapolcai Basin and the basalt plateau of Mount Kab embellish the basalt landscape. In the Balaton Upland, various basalt tuff outcrops are to be found. As a result of numerous phases of volcanic activity, the thickness of the basalt formation varies from 50 to 200 metres. In the crater basins and in the depressions of the tuff rings, oil shale occurs, originating from the algae which have settled there. The post volcanic activity has created the geyserite in the Tihanyi Peninsula. The basalt, basalt tuff and the geyserite are the most significant of the rocks surrounding the non-karstic caves in the Bakony Mountains (Fig. 2). On the mountain sides, accumulated loess is the most characteristic formation from the Pleistocene. The soft deposit offers a suitable material to construct artificial caves and cellars, but one natural cavity is also known in the loess.

Colluvium, redeposited tuff, fluvial sand and pebbles together with swamp deposits such as turf were deposited in the Holocene.

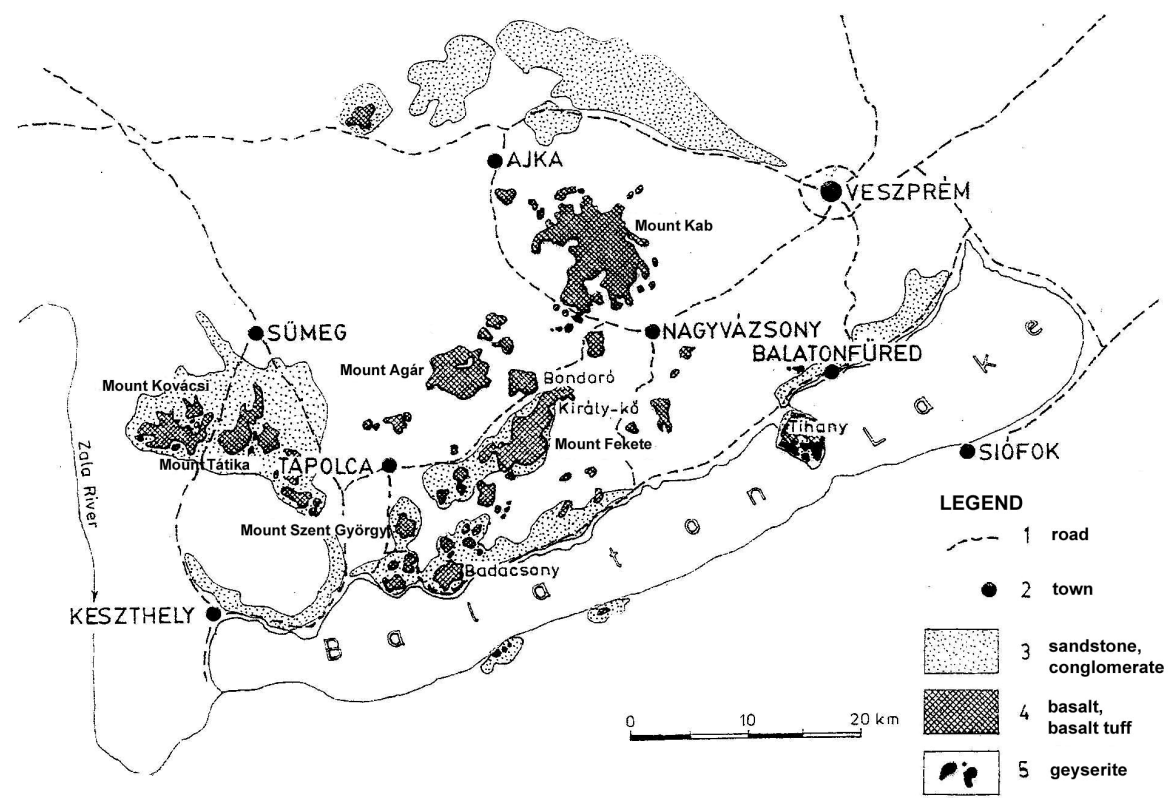

Fig. 2. Geological map of the surrounding rocks of the non-karstic caves in the Bakony Mountains 
NON-KARSTIC CAVE DEVELOPMENT IN THE BAKONY MOUNTAINS

The petrographic structure of the mountains is very varied. As a consequence, the 1000 caves which are to be found show diverse appearance and development (BERTALAN, 1958; ESZTERHÁS, 1983, 1984). The majority of the rocks are karstic limestone and dolomite, therefore, approximately $85 \%$ of the caves are karstic. The most significant karstic caves are the $4000 \mathrm{~m}$ long Csodabogyós Cave, the $3600 \mathrm{~m}$ long Alba Regia Cave, the $2400 \mathrm{~m}$ long Cserszegtomaji Well Cave and the hydrologically important Spring Cave of Héviz.

There are also numerous non-karsic caves. Within the framework of this study we cannot describe all of these caves. We only intend to present some examples to show the diversity of the non-karstic caves. Up to 2011, 147 natural non-karstic caves and 35 artificial cavities have been listed in the Bakony Mountains. The total length of the natural non-karstic caves is $991 \mathrm{~m}$. The longest caves are the $151 \mathrm{~m}$ long Pulai Basalt Cave (Fig. 6, Pict. 4), the $72 \mathrm{~m}$ long Halász Árpád Cave (Fig. 8) and the $51 \mathrm{~m}$ long Kapolcsi Pokol Hole (Fig. 5, Pict. 3). Eighty-four non-karstic caves have developed in sedimentary rocks such as sandstone, conglomerate, geyserite and loess, while 63 caves have formed in basalt and basalt tuff (ESZTERHÁS and SZENTES, 2004, 2009, 2010).

The nonkarstic caves according to their development can be classified into 16 genotypes with four categories (ESZTERHÁS, 1993; OZORAY, 1960; SZENTES 2010) (Table I.). 


\begin{tabular}{|c|c|}
\hline Genotypes of the Caves & Examples: \\
\hline \multicolumn{2}{|l|}{ I. Syngenetic caves } \\
\hline 1. Gas bubble cavities & Gas bubble cavity in the Castle Hill of Szigliget \\
\hline \multicolumn{2}{|l|}{ 2. Explosion Caves } \\
\hline a) steam explosion caves & Explosion Cave near the village of Gödrös \\
\hline 3. Caves in geyserite. & Tihanyi Spring Cave \\
\hline \multicolumn{2}{|l|}{ II. Postgenetic Caves } \\
\hline \multicolumn{2}{|l|}{ 1. Caves originated through mass movement } \\
\hline \multicolumn{2}{|l|}{ a) Tectonic caves } \\
\hline $\begin{array}{l}\text { - Caves formed parallel to the rim of the } \\
\text { outcropping rock }\end{array}$ & Kapolcsi Pokol Hole \\
\hline $\begin{array}{l}\text { - Caves developed perpendicular to the rim } \\
\text { of the outcrop }\end{array}$ & Lower Cave of Köudvar \\
\hline $\begin{array}{l}\text { - Caves formed along the downcast faults of } \\
\text { the basalt layers }\end{array}$ & Pulai Basalt Tuff Cave \\
\hline b) Atectonic caves & Vadlány Hole \\
\hline c) Break up Caves & Pulai Basalt Cave \\
\hline d) Consequence caves & $\begin{array}{l}\text { Basalt Quarry Cave near the village of Badacso- } \\
\text { nytomaj }\end{array}$ \\
\hline e) Talus caves & Little Sárkány Ice Cave \\
\hline \multicolumn{2}{|l|}{ 2. Fragmentation caves } \\
\hline \multicolumn{2}{|c|}{ a)Caves originated through temperature and moisture variation } \\
\hline - Fragmentation caves & Kö-hegyi Cave \\
\hline - Cavities between basalt columns & Lépcső-menti Cave \\
\hline \multicolumn{2}{|l|}{ 3. Caves originated through chemical weathering } \\
\hline a) Alkaline solution caves & $\begin{array}{l}\text { Upper Hole of the Aranyház Geyser Cone in } \\
\text { Tihanyi Peninsula }\end{array}$ \\
\hline \multicolumn{2}{|l|}{ III. Complex cave development } \\
\hline Gas bubble + Artificial & Halász Árpád Cave \\
\hline Geysirite deposition + Alkaline solution & Csúcs- hegyi Spring Cave in Tihanyi Peninsula \\
\hline IV. Artificial cavities & Cave Monastery in Tihanyi Peninsula \\
\hline
\end{tabular}

Table I.: Genotypes of the non-karstic caves in the Bakony Mountains 
The syngenetc cavities, which formed concurrently with the processes of the rock formation, belong to the first category. Three different types of syngenetic caves occur in the Bakony Mountains. Three gas bubble cavities open in the Castle Hill of Szigliget and on Mount Kab. Four caves are the result of a steam explosion and 41 caves have developed concurrently with the geyserite deposition on the Tihanyi Peninsula. Only the central part of the geysirite, caves are syngenetic, their further cave development due to alkaline solution. Unfortunately, 20 geyser cones with caves were demolished for building material in the first part of the 20th century.

\section{Kö-HEGYI CAVE}

\section{Surveyed by: I. Eszterhás}
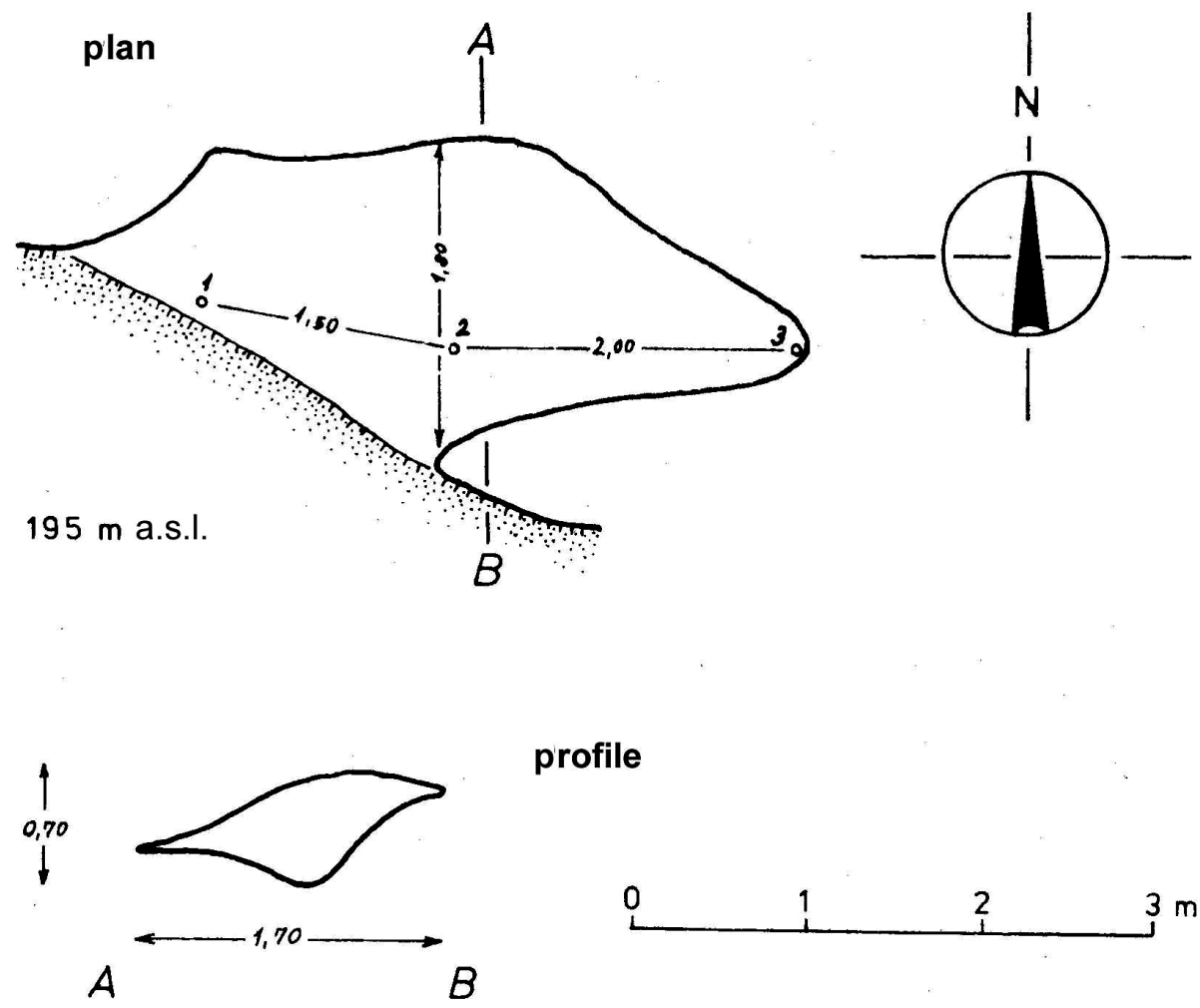

profile

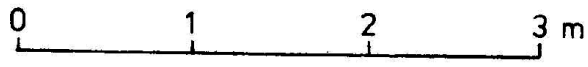

Fig. 3. Survey of the Kö-hegyi Cave 


\section{TIHANYI SPRING CAVE}

\section{Tihanyi Peninsula}
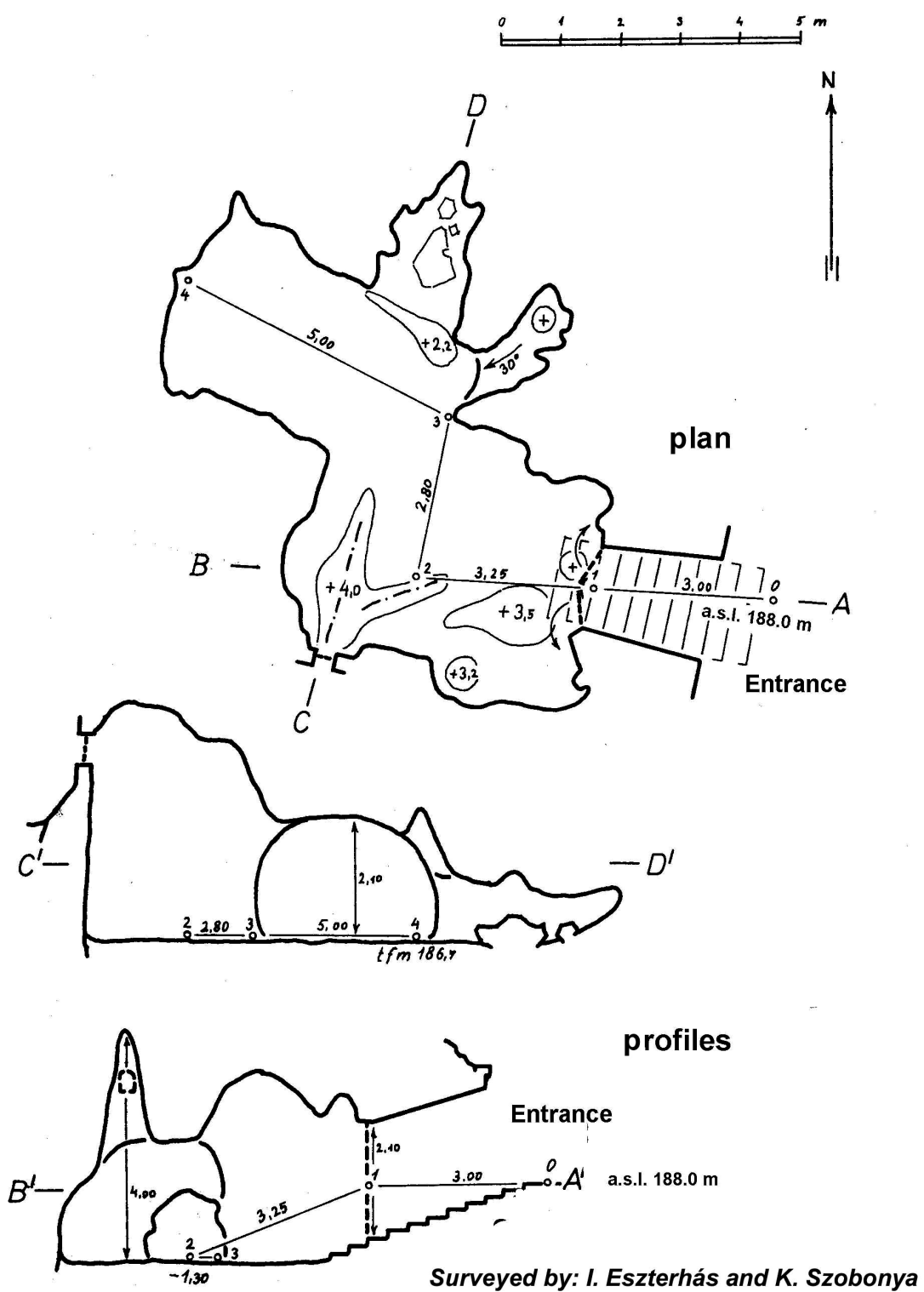

Fig. 4. Survey of the Tihanyi Spring Cave 

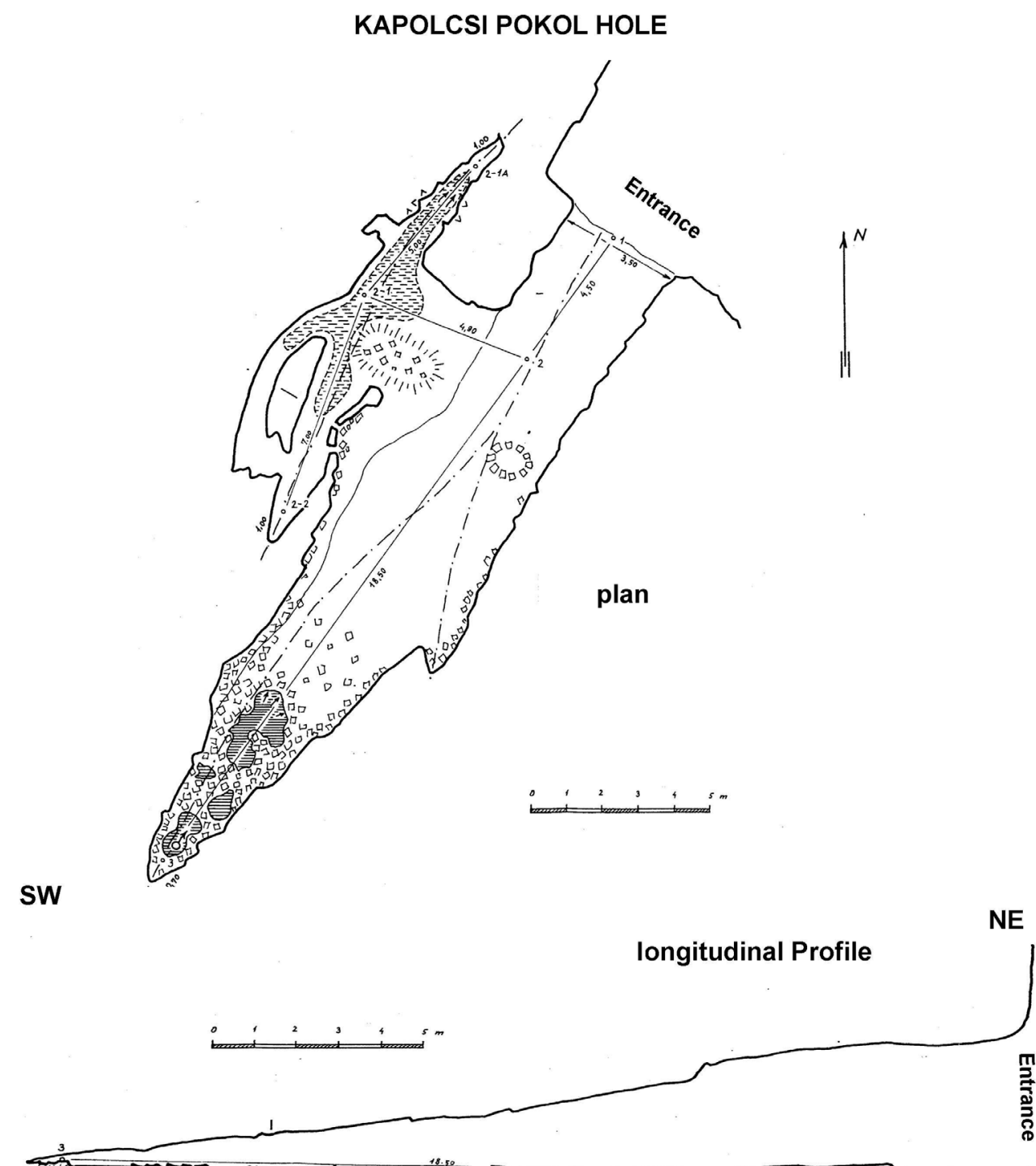

Surveyed by: I. Eszterhás and I. Gönczöl

Fig. 5. Survey of the Kapolcsi Pokol Hole 
Most of the non-karstic caves have postgenetic origin and show various genotypes.

The tectonic caves originated through mass movement, and were formed as a result of the shifting of the rock masses. Thirty-four tectonic caves are known in the Bakony Mountains. The basalt surface forms steep rims, because of the intense denudation of the surrounding sediments. As a consequence of that, the basalt layer lost the support and cracks are forming in the basalt. The cracks develop into caves after the further denudation of the sediments. Finally, some rims break down and collapse. Three different orientations of the potential cave developing cracks can be distinguished, in consequence of that three different types of tectonic caves are to be found. These are the caves which have developed perpendicular to the rim of the outcrop, caves which have formed parallel to the rim of the outcropping rock formation, and caves have formed along the downcast faults of basalt layers. Twentyone tectonic caves have formed parallel to the rim of the outcropping rock in the Bakony Mountains. The most significant are the $51 \mathrm{~m}$ long Kapolcsi Pokol Hole (Fig. 5, Pict. 3), the $39 \mathrm{~m}$ long Remete Cave near the village of Zalaszántó and the $26 \mathrm{~m}$ long Araszoló Cave. Twelve tectonic caves have developed perpendicular to the rim of the outcrop. The denudation of certain parts of the basalt rims varies. The blocks which denudate faster, down fault and separate themselves from the neighbouring basalt layers, forming perpendicular faults to the rim. The dilatation of the dominant faults results in this type of tectonic caves. Such caves include the Lower Cave of Köudvar, the Gyöny-tavi Cave near the village of Köveskál and probably the partly collapsed Bél-féle Sárkány Cave. The Pulai Basalt Tuff Cave has formed by the downcast faults of basalt layers.

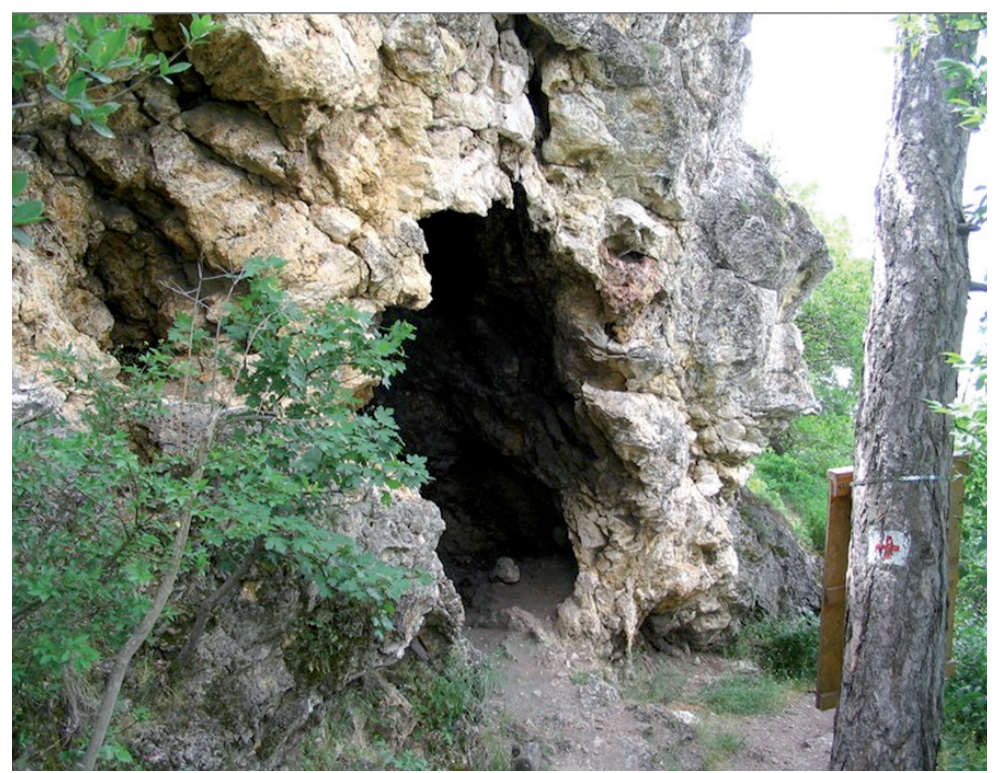

Pict. 1. Entrance to the Csúcs-hegyi Spring Cave in the geyser cone 
Atectonic caves were formed by the dilatation of the cracks as the rock mass moved down the slope. Five of these caves can be observed in the Basalt Street on Mount Kovácsi. From the rim, basalt blocks have separated off, and are sliding down on the convex slope of the sandstone and marl surface. The sliding induces cracks in the basalt blocks, which can widen into cave size as they slide further. Caves originating from such dilatation are the $24 \mathrm{~m}$ long Vadlány Hole (Fig. 7. Pict. 5.), the $12 \mathrm{~m}$ long
Kökamra and the $7 \mathrm{~m}$ long Basalt Street Niche.

Break up Caves form when the roof of a cavity loses its stability and collapses partly or completely due to the lower layers being washed out. The original cavity becomes filled with debris and in the upper part develops a new hollow, the so-called break up cave. The most significant break up cave in the Bakony Mountains is the 151 m long Pulai Basalt Cave (Fig. 6, Pict. 4) (ESZTERHÁS, 1986).

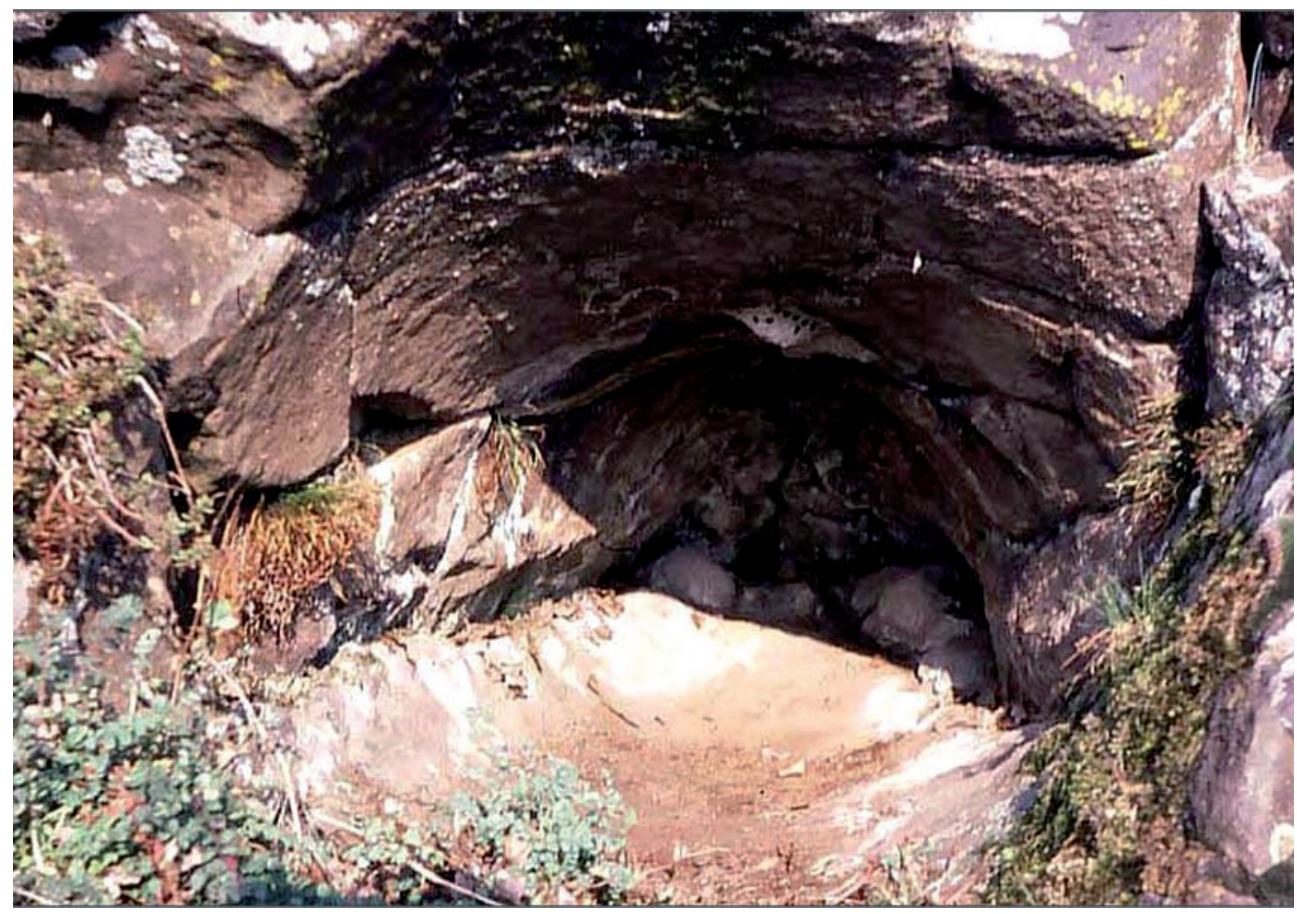

Pict. 2. Remains of the Explosion Cave of the Castle Hill of Szigliget

The consequence caves are a particular example of caves which have originated through collapse. The natural collapse of ceilings in artificial cavities (mine, cellar, dungeon) may form apparently natural holes in the higher elevations of a system. In the Bakony Mountains, only one consequence cave is known, the $3 \mathrm{~m}$ long Basalt Quarry Cave near the village of Badacsonytomaj. 


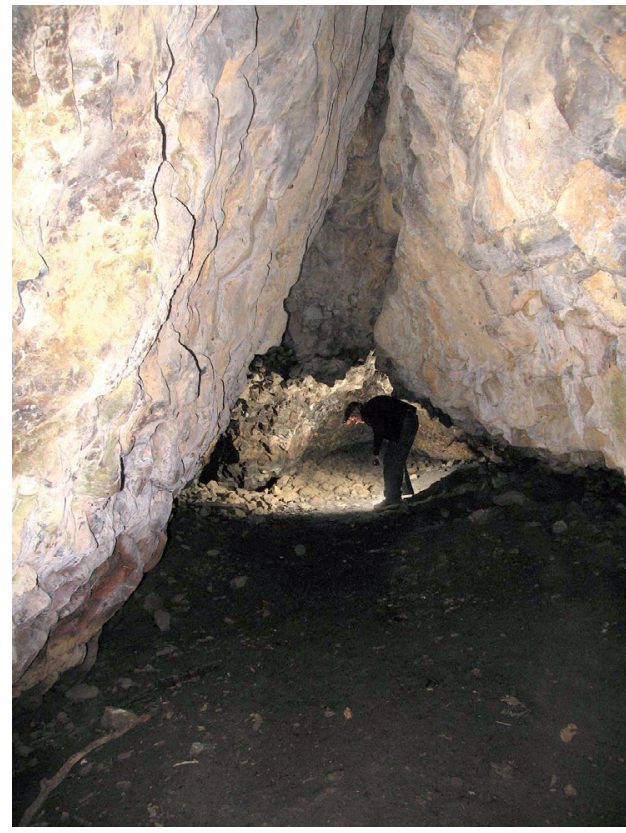

Pict. 3. Kapolcsi Pokol Hole

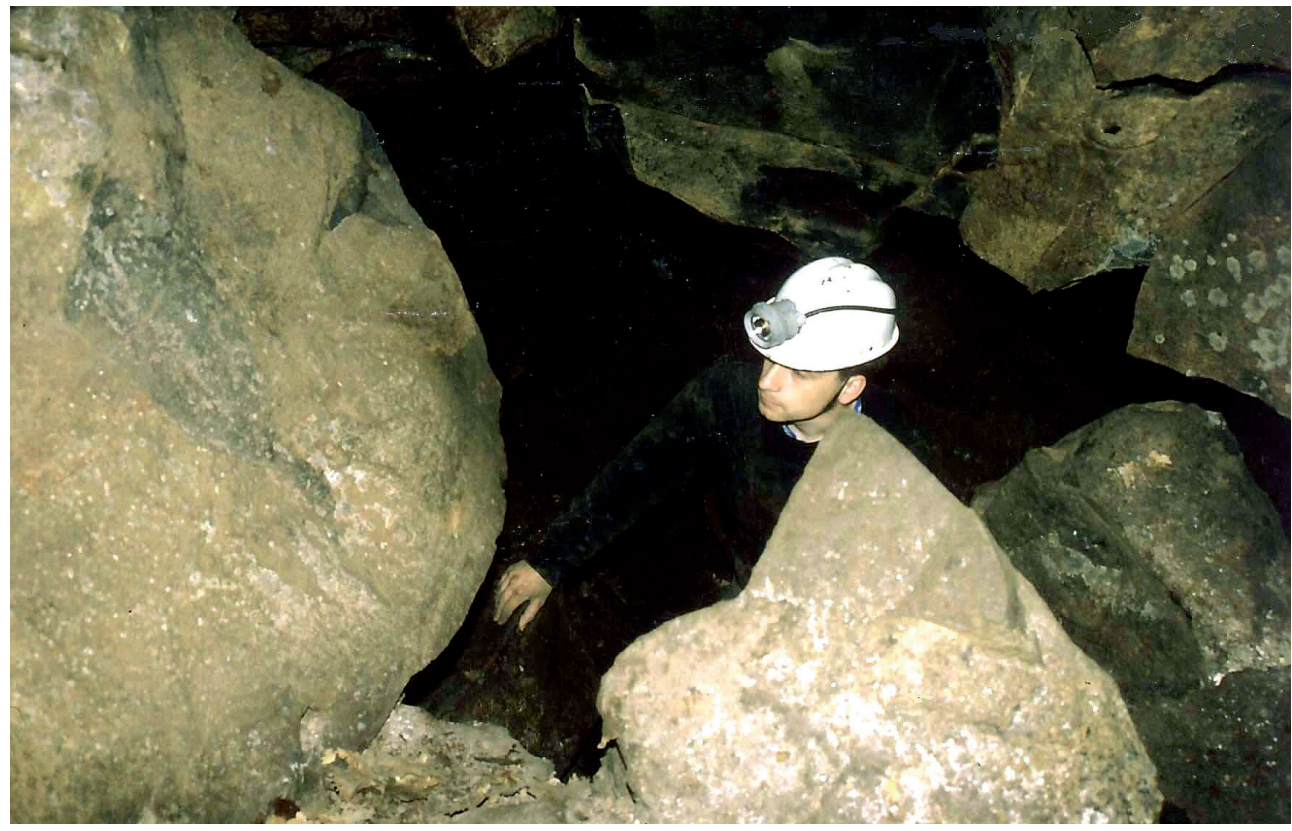

Pict. 4. Pulai Basalt Cave, in the background disc-shaped isingerit can be seen on the wall 
Three talus caves represent the pseudocaves in the Bakony Mountains. The Little Sárkány Ice Cave and the Big Sárkány Ice Cave on Mount Szent György and the Gyöngy- tavi Pseudocave near the village of Köveskál are to be found between the accumulated basalt blocks below the basalt rims.

Fifty-four caves have developed through fragmentation in the Bakony Mountains. Fragmentation through temperature and moisture variation attacks the basalt, the sandstone and the conglomerate, which results in smaller caves and rock shelters. Thirty-seven caves have formed through typical fragmentation. The rock forming minerals react to altering physical influences (temperature, moisture) with different volumetric expansions, which cause tiny cracks, then holes which occur in the place of fragmenting minerals. These type of fragmentations are to be found in Kö-

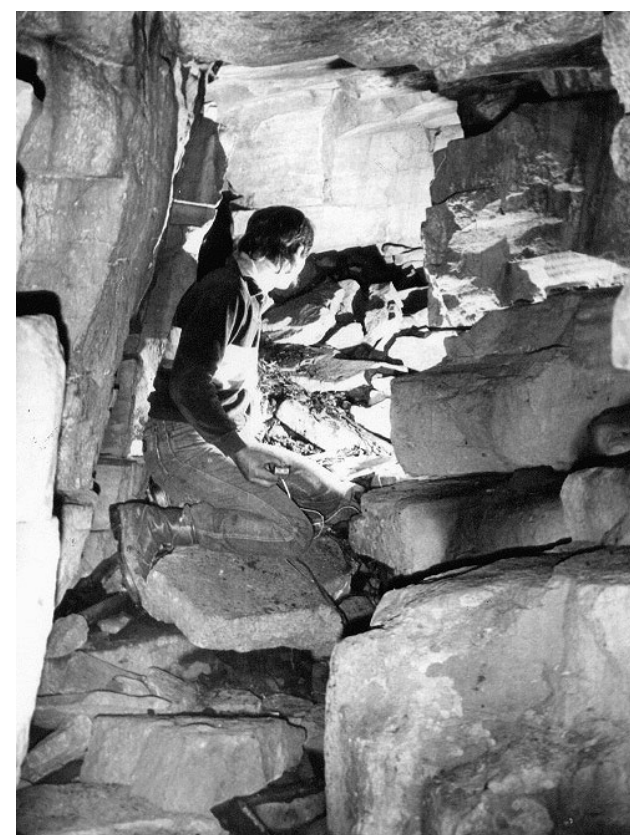

hegyi Cave (Fig. 3) near the village of Szentbékálla, in the Kerek-kő Cave near the settlement of Gyulakeszi, which has developed in sandstone and in Northern Cave near the village of Ajkarendek which has formed in conglomerate. The specific fragmentation of the basalt forms cavities between basalt columns. These are narrow, high caves or shafts. Seventeen cavities between basalt columns are listed among the basalt columns of the rims. In Mount Szent György, the Lépcsö-menti Cave (Pict. 7) and the Kilátó-alatti Cave, in Mount Badacsony the Hedera Cave, the Cirmos Cave and in Mont Somlyó the Sziklakonyha Cave are to be found between the basalt columns. In Mount Tátika, the Fekete-oszlopos Cave has formed between the basalt colums which have slid apart. In the Bakony Mountains, it is difficult to separate the cave development originating from altiplanation, from that origination from fragmentation. 


\section{PULAI BASALT CAVE}

Surveyed by: I. Eszterhás, I. Gáspár and I. Gönczöl
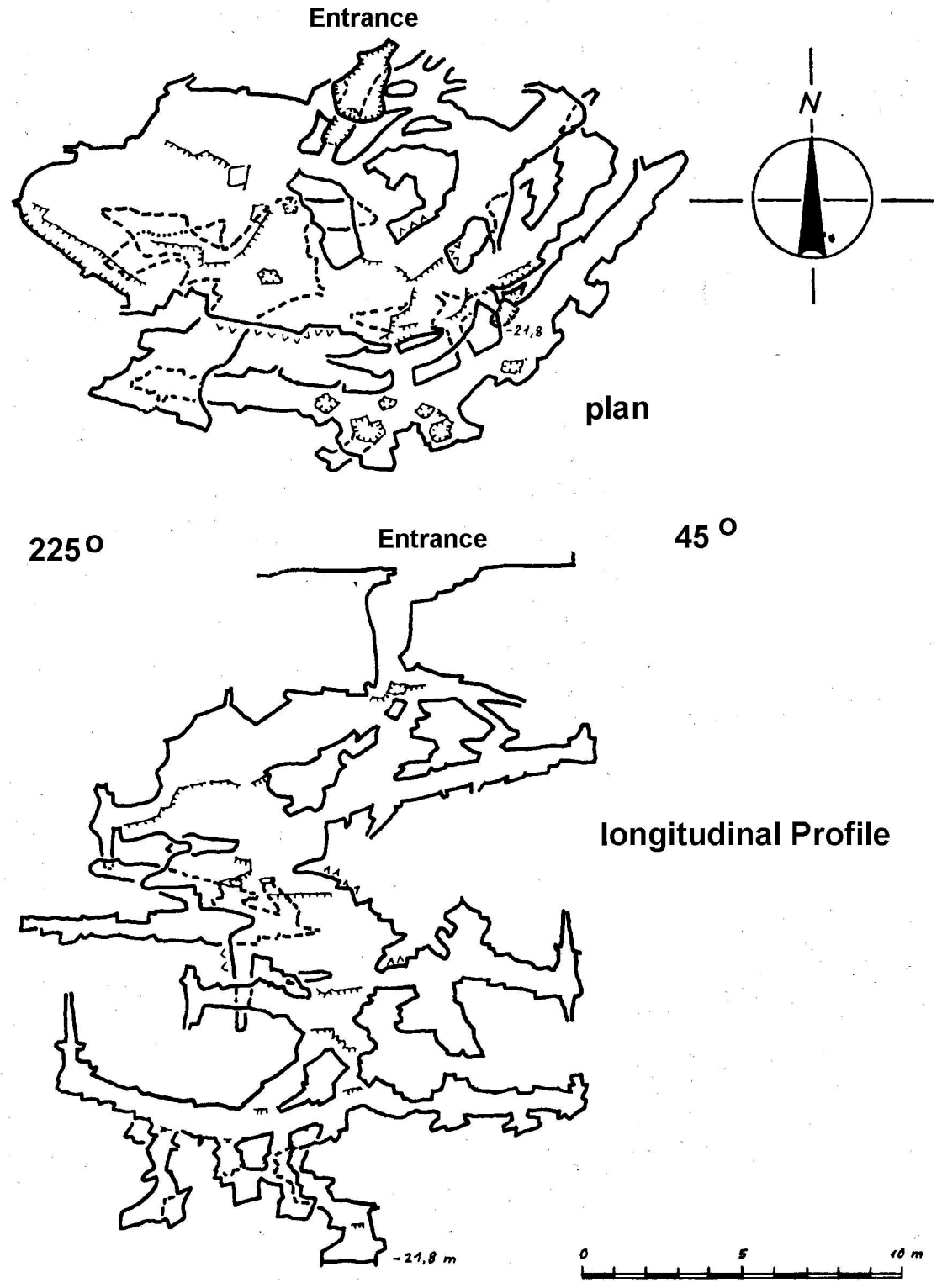

Fig. 6. Survey of the Pulai Basalt Cave 
Chemical weathering has resulted in the formation of different types of solution caves. Acidic solution, which forms cavities in karstic rock, is not the subject of the present study. The non-karstic rocks (basalt, geyserite, sandstone) contain large amounts of silicate. In the nature, the resulting acid can not dissolve the siliceous material. Solution is only possible in an alkaline environment. The lye on the surface or in the subsurface zone can originate from postvolcanic activity or, rarely, from the decomposition of the organic acids. Alkaline solution has been partly responsible for the formation of what were originally syngenetic geysirite caves in the Tihanyi Peninsula. The geysirite formation is diverse as regards the deposition and the chemical reactions of the solutions. The precipitated and consolidated silicate (geysirite) dissolves, if the $\mathrm{pH}$ value of the solution exceeds 8. Accordingly, solutions over $\mathrm{pH} 8$ produce geyser activity in the 41 geyserite caves alkaline solution occurred (ESZTERHÁS, 1987-b).

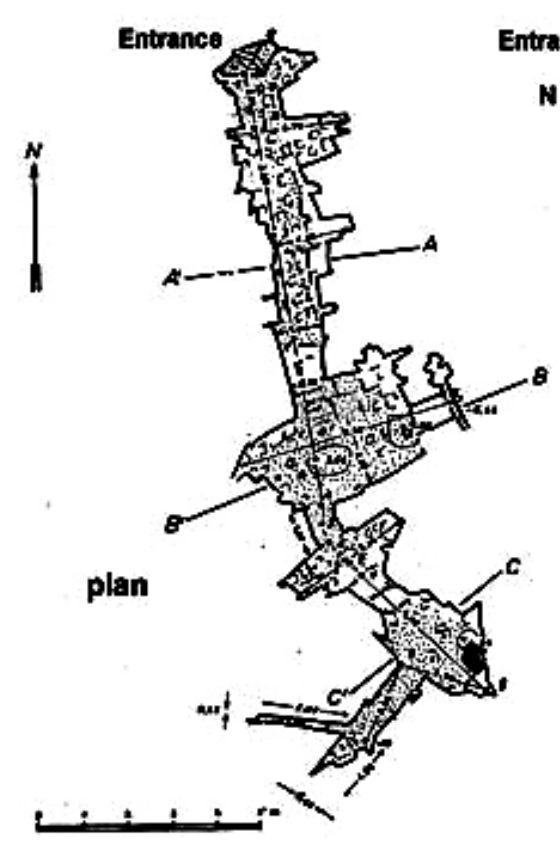

\section{VADLANY HOLE}

\section{Surveyed by: I. Eszterhás}

Fig. 7. Survey of the Vadlány Hole 
Another cave development category is the complex cave development. It is possible in each individual caves to detect several cave forming factors. Nevertheless, it is necessary to create a category where the presence of several cave forming factors are approximately equivalent. In this case, it is difficult to define the main factor. Such a cave is the $72 \mathrm{~m}$ long Halász Árpád Cave (Fig. 8) on Mount Kab. The cave is partly artificial because a series of gas bubble cavities have connected to the tunnel of a mining company. We can also include here the geysirite caves in the Tihanyi Peninsula, which have formed partly syngenetically with geysirite deposition and partly postgenetically by alkaline solution.

Some artificial cavities are considered to be caves by the local population. In the Bakony Mountains, 28 cave-dwellings in loess have been listed. Nineteen of these cave-dwellings have collapsed, only 9 cavities of the Tatár Holes near the village of Balatonkenese are still in existence. In the Tihany Peninsula, a Cave Monastery was carved in the basal tuff nine centuries ago. Seven cavities of the monastery can still be seen.

DESCRIPTION OF SOME CHARACTERISTIC CAVES ACCORDING TO THE TYPES OF CAVE DEVELOPMENT AND THE SURROUNDING ROCK

The present study has selected and reviews the 18 most significant and characteristic caves of the 147 natural nonkarstic caves and 35 artificial cavities in the Bakony Mountains.

Ten caves open in sandstone. Each of the 10 sandstone caves have developed by fragmentation through temperature and moisture variation. A peculiar surface formation, the "Stone Sea" of Mount Kö is to be found at $207 \mathrm{~m}$ above the sea level to the west of the village of Szentbékálla. Here the most characteristic rock figure is the Kelemen Stone. The covering rock slab of the stone formation is subject to movement. The 2.5 meter wide and $90 \mathrm{~cm}$ high entrance to the Kö-hegyi Cave (Fig. 3.) opens in the south-western side of Kelemen Rock. The cave is a $3.25 \mathrm{~m}$ long gradually narrowing, lenticular niche. The surrounding rock is Pannonian siliceous sandstone. The cementation of the sandstone is uneven. The fragmentation of the loosest part of the sandstone has resulted in a cave.

In several locations of the Bakony Mountains, calcareous or siliceous conglomerate occurs. Thirty-two small caves are known in conglomerate formation. Mount Ajka near the village of Ajkarendek is composed of Miocene marly limestone, which is overlain by Upper Pliocene marly, limy quartz and limestone pebble conglomerate. Three caves are to be found in the conglomerate at the boundary between the two rock layers. The most characteristic is the $6.5 \mathrm{~m}$ long crawling passage of Northern Cave. The cave development began with the formation of a cavity through the loosening and eroding of the underlying sediments. The resulting small cavities in the fragmented conglomerate, gradually formed into larger cavities.

Geysirite occurs mainly on the Tihanyi Penninsula. Smaller outcrops of geysirite are located in the Koloska Valley and near the village of Pula. It is reputed that originally $130-150$ geyser cones existed on the Tihany Peninsula. Seventy-nine cones were identified in 1983, but many of them were partly demolished (ESZTERHÁS 1987-b). Since the development of the 
geyserites, caves are dependent on the geyser cones, many of these caves are the victims of quarry operations. Recently, 22 geyserite caves or the ruins of geyserite caves were identified. The most important caves are the Csúcs-hegyi Spring Cave and the Tihanyi Spring Cave.

The Tihanyi Spring Cave is a gated show cave (Fig. 4). The fourteen metre long cave is composed of two chambers and two bigger niches. The walls are decorated with spectacular solution forms, which also form the vault of the ceiling. In the first chamber, two striking joints and a layered hydroquartzite formation overlain by compact limy-siliceous geyserite can be observed. Some solution forms are covered with secondary calciferous coatings. Near the cave entrance and in the second chamber, walnut and apple-sized opal concretions can be seen. The artificial widening in the cave crops out nicely the structure of the geyser cone.

The Csúcs-hegyi Spring Cave (Pict. 1) opens in the Tihanyi Peninsula in the western side of Mount Nyereg. The entrance to the cave is $3.2 \mathrm{~m}$ high and $2.7 \mathrm{~m}$ wide. Behind the entrance runs a $4.2 \mathrm{~m}$ long and $3 \mathrm{~m}$ wide oval chamber. There is no vaulting, in the wall only minor salient and flares appear. From the chamber a 6.5 metre high and $20-25 \mathrm{~cm}$ diameter chimney opens to the surface. Between the chimney and the cave entrance a $4.3 \mathrm{~m}$ high blind chimney rises. The surrounding geysirite is made up of cellular hydro-quartzite with minor lime content. Compact chalcedony occurs in a 3-4 m section of the chamber. On the hydroquartzite surface solution forms, there are traces of the cave having developed in an alkaline solution.

Fifty-six caves have formed in the alkaline basalt in the Bakony Mountains.
We describe the most characteristic ten basalt caves.

Two gas bubble cavities formerly existed in the basalt dyke of Castle Hill at Szigliget Village. One of the cavities has been completely demolished. The remains of the other cavity in columnar basalt, the so-called Explosion Cave of Castle Hill of Szigliget (Pict. 2) still exists (ESZTERHÁS, 1987-a). The surface of the bell shaped, 130 cm long hole is perfectly smooth. An $85 \mathrm{~cm}$ long syncline in the foreground indicates the original $215 \mathrm{~cm}$ length of the cavity. At the end of the hole, a 5-6 cm diameter tube dipping down at an angle can be observed, which probably marks the place of inflow of the blowing gases.

The 51 metre long Kapolcsi Pokol Hole (Fig. 5, Pict. 3) has formed parallel to the rim of the outcropping basalt (ESZTERHÁS, 1984-a, 1985). The basalt is underlain by a loose sandstone layer and its rim has broken away. The basalt blocks have not slid down on the slope, but leant against the bedrock, forming a tectonic cave, which is parallel to the verge. In the sandstone, thick basalt blocks dam up the seeping water, which emerges in the cave as a spring. This spring feeds a small lake. The size of the lake varies, because after the water reaches a certain level a siphon system drains it.

On the western slope of Mount Tátika there is a similar original tectonic cave, the $39.2 \mathrm{~m}$ long Remete Cave. Behind the 1.2 $\mathrm{m}$ wide and $3 \mathrm{~m}$ high entrance a gradually narrowing, funnel-shaped corridor leads to the high and narrow main passage. The vertical extent of the cave is $20.4 \mathrm{~m}$, but the average width is only $40-50 \mathrm{~cm}$. The cave wall is composed of columnar basalt. The basalt columns are coated with white calcite speleothems, which stems from the 
overlaying calcareous sand (ESZTERHÁS, 1987-a).

The Lower Cave of Köudvar is to be found also in Mount Tátika. Behind the 1 $\mathrm{m}$ high and $60 \mathrm{~cm}$ wide entrance runs a 5.1 $\mathrm{m}$ long crawling passage. The significance of the cave is the perpendicular development to the rim of the basalt outcrop (ESZTERHÁS, 1988-a).

The 151 meter long and $21 \mathrm{~m}$ deep Pulai Basalt Cave (Fig. 6, Pict. 4) is a break up cave (ESZTERHÁS, 1985). The 25-30 m thick basalt is underlain by soluble limestone. Along the cracks in the basalt, seeping water has dissolved holes in the limestone, into which the basalt layer has broken. The cave is accessible through a narrow shaft, which leads to a bigger chamber. From this chamber various small passages and shafts open in different directions. The cave wall shows nicely the different basalt layers, which are the witness to the several thousand years of volcanic activity. In the cave, a rare silicate mineral can be found, the disc-shaped isingerit.
The atectonic Vadlány Hole (Fig. 7, Pict. 5) is the most remarkable cave on the Mount Kovácsi. The irregular quadrangular entrance shaft to the cave is a 45 degree slope, which is divided into two openings by a jammed rock slab. Beneath the shaft a $2.7 \mathrm{~m}$ wide chamber opens out, which continues in a $6.8 \mathrm{~m}$ long, $1 \mathrm{~m}$ wide and $2-2.8 \mathrm{~m}$ high rectangular Entrance Passage. The walls are composed of fragmented gray basalt. The cave belongs to the atectonic development group of the postgenetic caves (ESZTERHÁS, 1988-b; OZORAY, 1960; SZENTES, 1971). The depths of the cave have formed concurrently with the Basalt Street on the surface. The basalt layer lost its support, tipped out and slid down on the concave slope. This movement has generated parallel and perpendicular expanding cracks to the main strike of the Basalt Street. One of the perpendicular cracks forms the longitudinal extent of the cave and several smaller parallel cracks can be observed in the wider parts of the cave. 


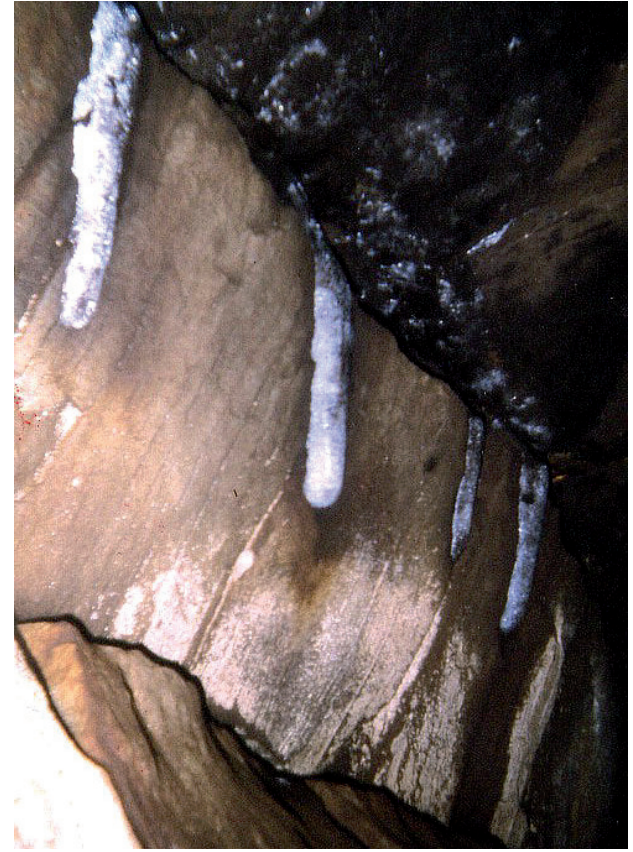

Pict. 6. Ice formations in summer in Big Sárkány Ice Cave

The Basalt Quarry Cave near the village of Badacsonytomaj is to be found in the wall of an abandoned basalt quarry. The cavity is a $5 \mathrm{~m}$ wide and $2.4 \mathrm{~m}$ high niche. The embayment of the hole is $2.9 \mathrm{~m}$. The small cavity is the only consequence cave in the Bakony Mountains. The hole was created by a break down during quarry operation.

The Little Sárkány Ice Cave opens on the northern side of Mount Szent György between the debris of collapsed basalt columns (ESZTERHÁS, 1994-b). The entrance to the cave is $2 \mathrm{~m}$ wide and $1 \mathrm{~m}$ high. The zigzag labyrinth is passable for a length of $6.7 \mathrm{~m}$. The cave is a so-called dynamic ice cave. In the summer season (March-September), the temperature of the outward flowing air is below freezing point, therefore, the condensed water gets cold

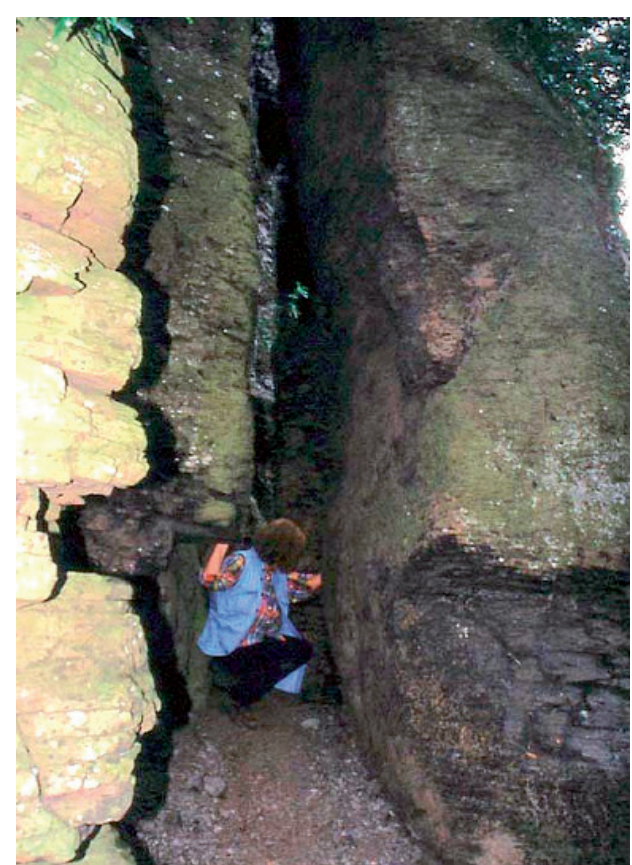

Pict. 7. Lépcső-menti Cave between the basalt columns in Mount Szent György

enough to form an ice crust on the basalt blocks. The speed of the outward flowing air is $5-15 \mathrm{~m} / \mathrm{sec}$, which spasmodically speeds up sometimes in every few minutes. In winter, the inflowing air does not cause ice coating. Nearby, in the $31 \mathrm{~m}$ long Big Sárkány Ice Cave the ice coating can similarly be observed (Pict. 6).

The cavities between basalt columns are specific fragmentation caves of the basalt rims. With favourable climatic and petrographic conditions the basalt rim can sometimes form 20-30 m high columns. The fragmentation results in single columns, which collapse later in the ultimate stages of their development. If the gravel can trickle from between the gaps in the columns, then high, narrow cavities form. Seventeen cavities between basalt columns have been 
listed in the Bakony Mountains. Most of them are to be found on Mount Szent György, for instance the 37 degree sloping, $2.3 \mathrm{~m}$ long and $7.6 \mathrm{~m}$ high Lépcső-menti Cave (Pict. 7).

One of the most significant non-karstic cave in the Bakony Mountains is the Halász Árpád Cave (Fig. 8). Halász Árpád was a geologist and cave explorer in the region. The cave is a $72 \mathrm{~m}$ long horizontal passage 4-5 $\mathrm{m}$ beneath the surface. Two shaft entrances lead to the cave (ESZTERHÁS 1988-c). The cave is filled with water up to the entrance shafts for the greater part of the year, only in a very dry summer is $20-25 \mathrm{~m}$ passable in the upper section. A complete study was carried out in the year 1987, after pumping the water out from the cave. The results have not clearly proved the origin. Probably, the holes were a range of gas bubble cavities, which were connected artificially during the mining operation and were used as a shelter and a store. In some places on the wall ropy lava formations and conical lava speleothems can be seen. After the mining operations were abandoned, groundwater has filled up the cavities.

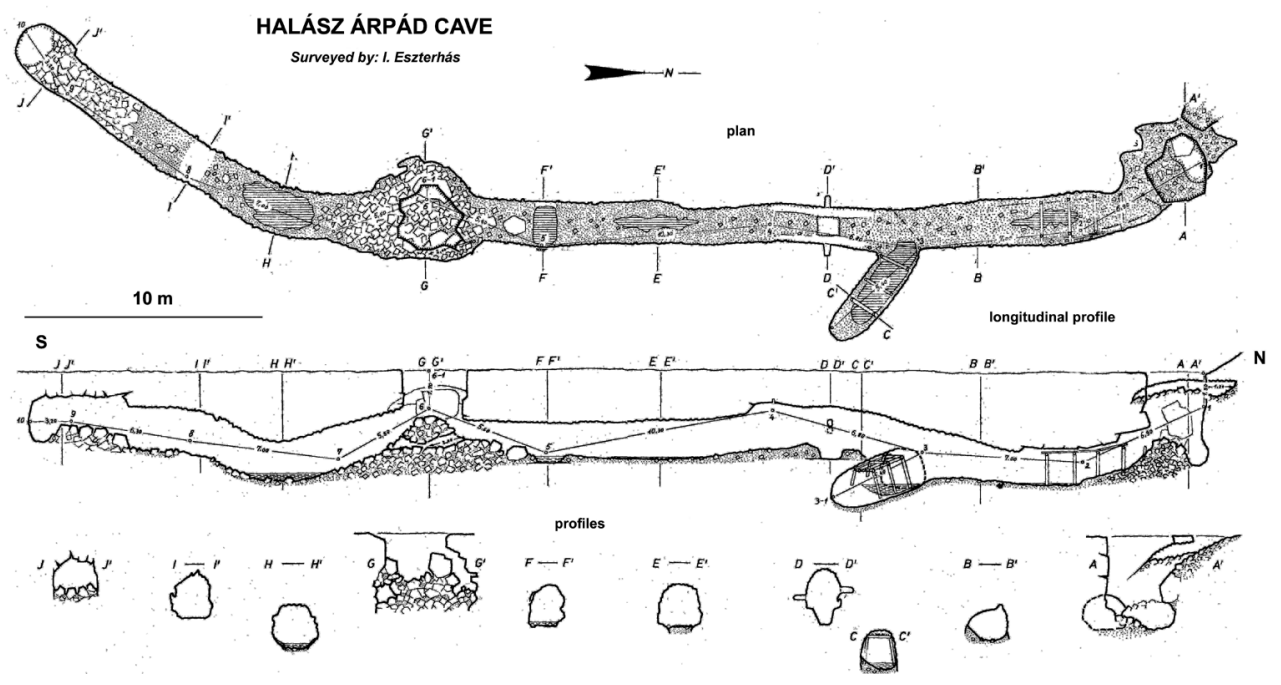

Fig. 8. Survey of the Halász Árpád Cave

In the basalt tuff, 7 caves have been listed. The most interesting is the Explosion Cave near the settlement of Gödrös. The 3 $\mathrm{m}$ high and $1.5 \mathrm{~m}$ wide entrance to the cave opens in the wall of an abandoned quarry. The $6.5 \mathrm{~m}$ deep cave is a $16 \mathrm{~m}$ long maze. The basalt tuffite walls were decorated with 3-4 mm sized calcite pizolites, which have been completely looted. The cave has developed through steam explosion (ESZTERHÁS, 1988-c). Due to a decrease in pressure, the streaming hot water, which was of volcanic origin and travelling upwards, suddenly volatilized. 
The consequent explosion stretched apart the loose, pyroclastic rock. In this way, an irregular-shaped hole was formed which was filled with a hot solution. From this solution precipitated minerals cemented the walls of the hole and deposited the calcite pizolite coating. The cave, which originally had no surface connection, was opened by quarry operations in 1930.

The Pulai Basalt Tuff Cave opens near the highway between the towns of Veszprém and Tapolca. The $10 \mathrm{~m}$ long low, but wide crawling passages of the cavity have been formed by the downcast faults of basalt layers.

Tihanyi Penisula

No. 2 Monk's Dwelling

Surveyed by: I. Eszterhás and l. Jákói 1983.
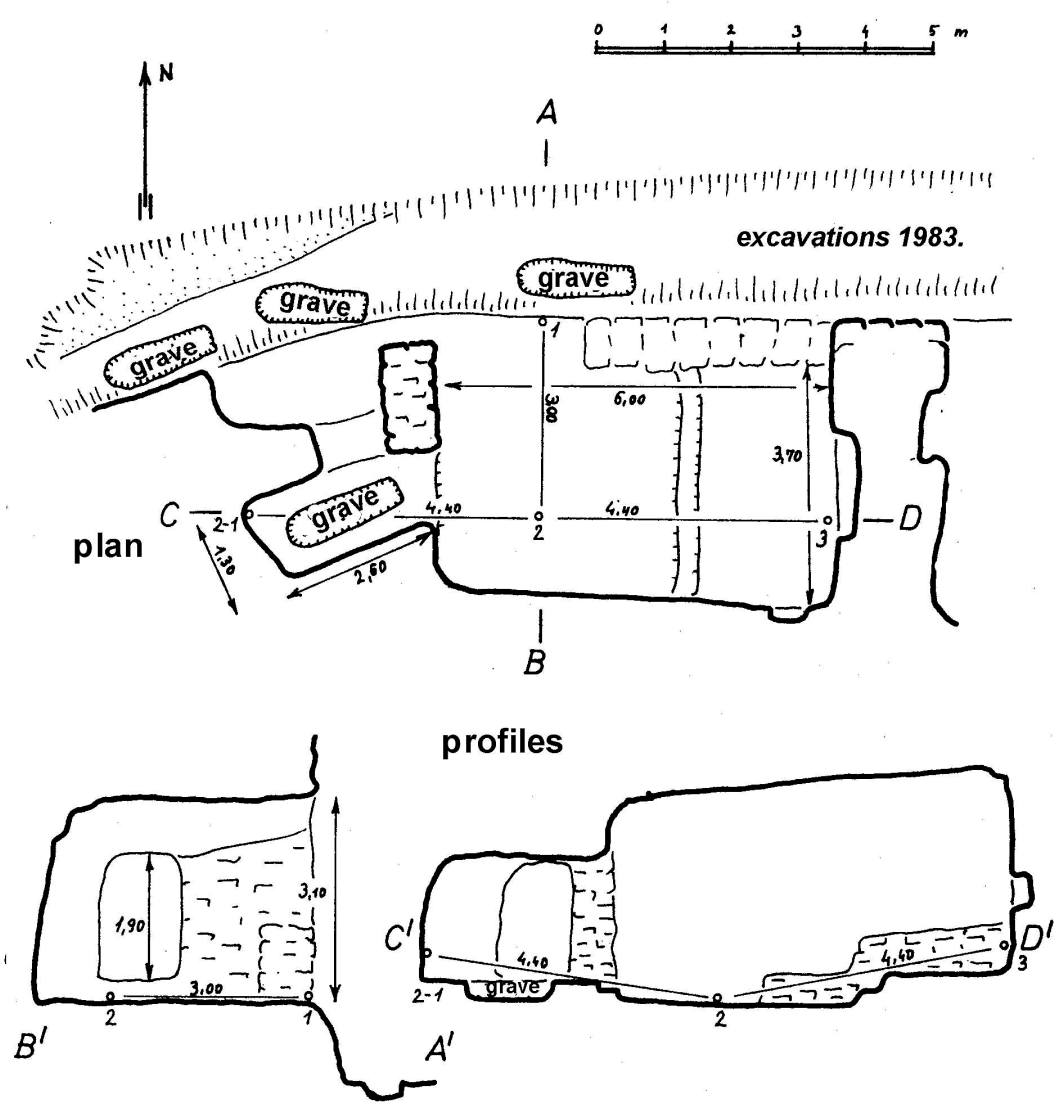

Fig. 9. Survey of the No. 2 Monk's Dwelling in the Tihanyi Peninsula 


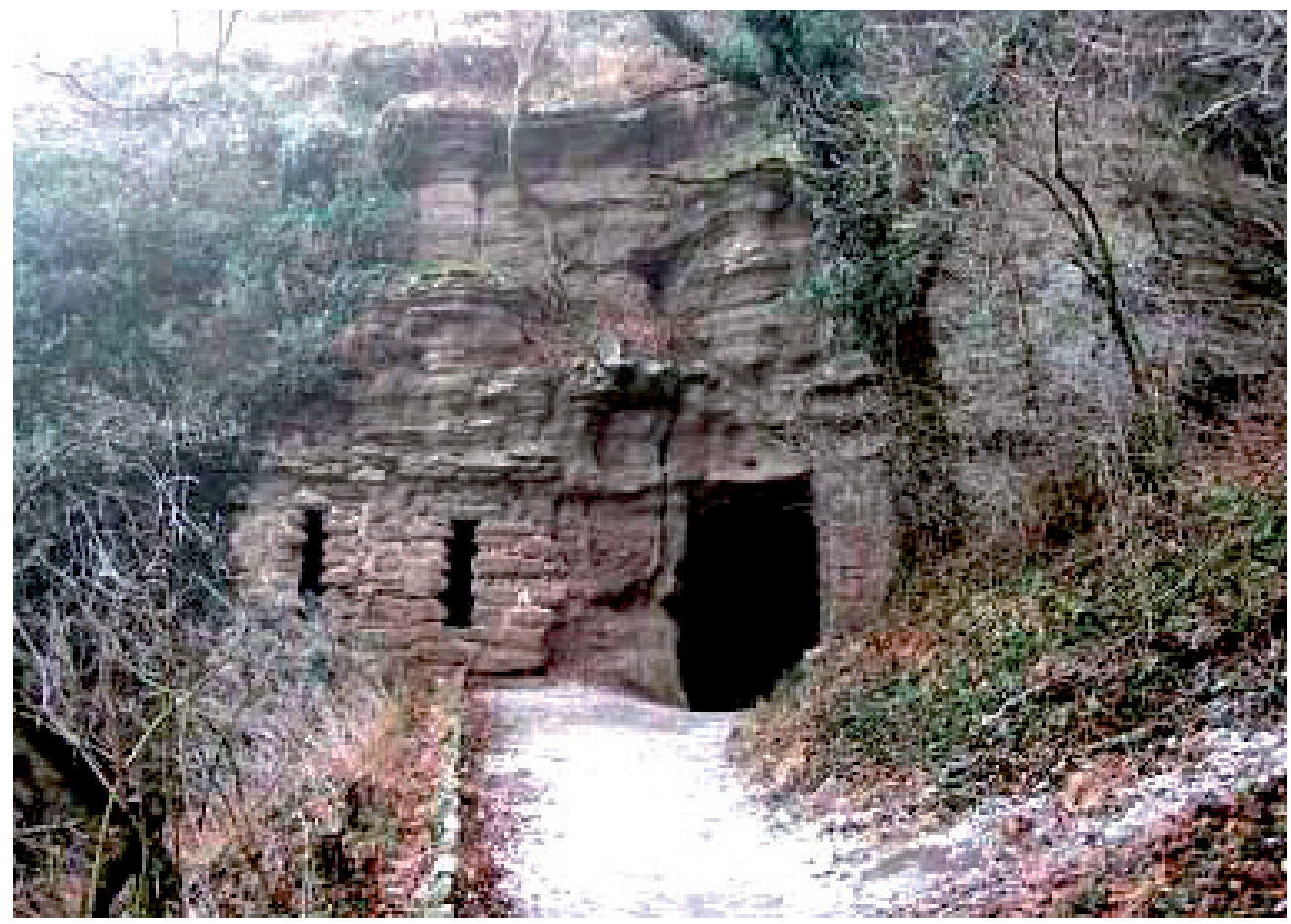

Pict. 8 Monk's Dwelling in Tihanyi Peninsula

As well as the 35 artificial cavities in the Bakony Mountains it is worth considering the Cave Monastery, the socalled monk's dwellings (Pict. 8.), which have been carved in the basalt tuffite of the Tihanyi Peninsula (ESZTERHÁS, 1987b; MEDNYÁNSZKY, 2009). The No. 2 Monk's Dwelling (Fig. 9) is a complex hole. The base area of the $3 \mathrm{~m}$ high main chamber is $6 \times 3.5 \mathrm{~m}$. Behind the chamber a $2.5 \times 1.3$ $\mathrm{m}$ sized cell opens where a carved grave is to be found in the bottom. In the MiddleAges, between the years 850 and 1350 active religious life took place in the monastery. Orthodox hermits from Greece lived here, and hollowed out their reclusories, chapel and dining-room. Later, the monastery was abandoned and through the centuries was devastated by collapses and looting. Recently, as a scheduled monument, the ruins have been partly renovated.

Near the village of Balatonkenese there were once 28 holes carved in the loess wall, but today only nine cavities remain. The local people call them Tatár (Tartar) Holes, however, their origin most probably is not from the age of the Tartar Invasion (1241-42), and this is just a folk tale (MEDNYÁNSZKY, 2009). The cavities were mentioned first in the year 1676. The biggest hole is the No. 7 Tartar Hole. The hole consists of two chambers, one $6 \mathrm{~m}$ long and the other $5 \mathrm{~m}$ long. Memorials and wall scrapes identify many cavity-dwellers and at the present time the hole is used as an occasional bivouac place. 


\section{SUMMARY}

The Bakony Mountains are the most complex geological region in Hungary. The mountains are composed of numerous sedimentary (chemogenic, clastic, and biogenetic) and volcanic (basalt and basalt tuff) rock formations. As a consequence, the speleology of the region is diverse. There are a large number of horizontal and vertical, wholly or partly flooded, cold or thermal water originating karstic caves. The non-karstic caves, which number 147, have developed through gas bubble, steam explosion, and geyserite deposition. There are also tectonic, atectonic, break up, talus, fragmentation and alkaline solution originating non-karstic caves. Some of them are flooded and two of them have ice coating.

\section{BIBLIOGRAPHY}

BERTALAN, K. (1958). Magyarország nem karsztos eredetü barlangjai (Nonkarstic Caves of Hungary) - Karszt- és Barlangkutatási Tájékoztató (jan-jún), Budapest: p.13-21.

BUCKÓ, E. (1970). A Tihanyi-félsziget geomorfológiája, In Bialik: Magyarázó a Balaton környéke 1:10.000 építésföldtani térképsorozatához Tihany. (Geomorphology of the Tihanyi Peninsula, In Bialik: Explanatory Note for the Engineering Geological Map of Lake Balaton Region - Tihany, 1 : 10 000) Hungarian Geological Survey Publication, Bp. 1970. p. 47-55.

CHOLNOKY, J. (1931). Tihany, morfológiai megfigyelések

(Morphological Observations In Tihany Peninsula) Matematikai és Természettudományi
Értesítö (48. köt. 1. füzet), Budapest p. 225- 227.

ESZTERHÁS, I. (1983). A Bakony barlangjai (Caves of the Bakony Mountains) - in Mészáros: Bakony, Balaton-felvidék - Medicina Könyvkiadó, Budapest p. 45-71.

ESZTERHÁS, I. (1984). Lista a Bakony barlangjairól (List of the Caves in the Bakony Mountains) - Folia musei historico-naturalis Bakonyiensis, Zirc p. 13-30.

ESZTERHÁS, I. (1985). A Kapolcsi Pokollik (The Kapolcsi Pokol Hole) - Folia musei historico-naturalis Bakonyiensis, Zirc p. 39-42

ESZTERHÁS, I. (1986). A Pulaibazaltbarlang és környéke (The Pulai Basalt Cave and its surrounding)- Karszt és Barlang (I. füzet), Budapest p. 23-32.

ESZTERHÁS, I. (1987-a). A Bakony bazaltbarlangjai (Basalt Caves in the Bakony Mountains) - Föld és Ég (22. évf. 12.sz). Budapest p. 360-364.

ESZTERHÁS, I. (1987-b). A Tihanyifélsziget barlangkatasztere (List of the Caves in the Tihanyi Peninsula) - Bakony Természettudományi Kutatásának Eredményei (18. köt). Zirc p. 1-84.

ESZTERHÁS, I. (1988-a). A Tátika bazaltbarlangjai (Basalt Caves in Mount Tátika) - Folia musei historico-naturalis Bakonyiensis (7. sz.) Zirc, p. 13-22.

ESZTERHÁS I. (1988-b): A Kovácsi-hegy bazaltbarlangjai (Basalt Caves in Mount Kovácsi) Folia musei historico-naturalis Bakonyiensis (7. sz), Zirc, p. 23-36.

ESZTERHÁS, I. (1988-c). A magyarországi bazaltbarlangok kutatottságának eredményei (Results of Basalt Cave Research in Hungary) - Karszt és Barlang (1988 I. füzet), Budapest p. 15-20. 
ESZTERHÁS, I. (1984-a). A Pokol-lik (The Pokol Hole) - Lychnis, a Vulkánszpeleológiai Kollektíva kiadványa, Kapolcs p. 28-35.

ESZTERHÁS, I. (1984-b). Magyarország jégbarlangjai (Ice Caves in Hungary) - Lychnis, a Vulkánszpeleológiai Kollektíva kiadványa, Kapolcs p. 36-42.

ESZTERHÁS, I. (1993). Genotypes of caves in volcanic rocks in Hungary Conference on the karst and research activities of educational and research institutions in Hungary, Jósvafö p. 81-86.

ESZTERHÁS I. and SZENTES, G. (2004). Magyarország nemkarsztos barlangjainak katasztere - (A List of Non-karstic Caves in Hungary) http//:geogr.elte.hu/nonkarstic

ESZTERHÁS, I. and SZENTES, G. (2009). Overview of the Non-karstic Caves in Hungary, 15th International Congress of Speleology, Kerrwille, Texas, USA 2009, Proceedings, Vol. 3, p.1474 - 1480

ESZTERHÁS, I. and SZENTES, G. (2010). Caves formed in Volcanic Rock in
Hungary, Part I-II., XIV. Syposium on Vulcanspeleology, Queensland, Australia 2010, Proceedings, p. 179-196.

GYALOG, L. (2005). Magyarázó Magyarország fedett földtani térképéhez, 1:100 000 (Az egységek rövid leírása), (Explanation Note for Geological Map of Hungary, 1 : 100 000, Short descriptions of the units) Budapest, Hungarian Geological Survey.

JUHÁSZ, Á. (1987). Évmilliók emlékei (Relics from Millions of Years) Gondolat Kiadó, Budapest p. 1-562.

OZORAY, G. (1960). The genesis of non-karstic natural cavities as elucidated by Hungarian examples -Karszt- és Barlangkutatás (II. kötet), Budapest p.127-136.

MEDNYÁNSZKY, M. (2009). Magyarországi barlanglakások (Cave-dwellings in Hungary) - TERC Kereskedelmi és Szolgáltató Kft. Budapest p. 89-91, 177- 182.

SZENTES, G. (1971). Caves formed in the volcanic rocks of Hungary - Karszt- és Barlangkutatás (VI. kötet), Budapest p. 117-129. 